\title{
INFLUENCE OF USING SUGARCANE BAGASSE AND SUGAR BEET PULP WITH OR WITHOUT ENZYMES IN RABBIT DIETS: 1- ON GROWTH PERFORMANCE OF GROWING RABBITS
}

\author{
H.M. El-Tahan ${ }^{1}$, M.A.M. Sayed ${ }^{1}$, W.A. Morsy ${ }^{1}$, F.S. Ismail ${ }^{2}$ and M.R. Elgogry ${ }^{2}$ \\ ${ }^{1}$ Animal Production Research Institute, Agricultural Research Center, Ministry of Agriculture, Dokki, Gizza, \\ Egypt \\ ${ }^{2}$ Department of Poultry Productions, Faculty of Agriculture, Mansoura University, Egypt \\ *Corresponding Author: Tahan_Hossam@yahoo.com
}

\section{SUMMARY}

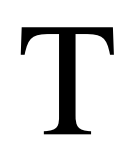

he aim of this study was to investigate the effect of using different levels of sugarcane bagasse (SCB) and sugar beet pulp (SBP) with or without enzyme in diets of growing APRI line rabbits on the productive performance. One hundred and forty-four APRI rabbits were divided randomly into nine experimental groups of 16 rabbits each ( 8 males +8 females) of 5 weeks of age with an average live body weight of (723 $\pm 2 \mathrm{gm}$.), were used in this study. The following 9 diets were obtained: control (0\% Sugarcane Bagasse and Sugar Beet Pulp), SCB50 diet (Sugarcane Bagasse replace to 50\% Berseem hay), SCB100 diet (Sugarcane Bagasse replace to 100\% Berseem hay), SCB50E diet (Sugarcane Bagasse replace to $50 \%$ Berseem hay with Kemzyme), SCB100E diet (Sugarcane Bagasse replace to 100\% Berseem hay with Kemzyme), SBP50 diet (Sugar Beet Pulp replace to 50\% Berseem hay), SBP100 diet (Sugar Beet Pulp replace to 100\% Berseem hay), SBP50E diet (Sugar Beet Pulp replace to 50\% Berseem hay with Kemzyme) and SBP100E diet (Sugar Beet Pulp replace to $100 \%$ Berseem hay with Kemzyme). All diets were nearly isonitrogenous, iso-caloric and contained similar levels of crude fiber and micro elements. Results indicated that there were no significant differences in body weight between rabbits fed SBP diet and rabbits fed control diet, while those fed SCB diet had the lowest body weight. Using Kemzyme increased the body weight insignificantly, except in weeks 10, 11 and 12, which Kemzyme significantly $(\mathrm{P}<0.05)$ increased body weight. During the whole experimental period $(5-13$ weeks of age), rabbits fed SCB diets recorded significantly the lower daily weight gain, as compared with those fed SBP and control diet (23.56 vs. 25.43 and 25.41 g, $\mathrm{P}<0.001$, respectively). Supplementing Kemzyme in diets had no significant differences on daily weight gain in all experimental periods. Feed intake in the whole period (5-13 weeks of age) significantly decreased by 3.5 and $5.1 \%$ for rabbits fed SBP and SCB diets, respectively, as compared with those fed control diet. Moreover, feed intake was decreased by $1.95 \%$ with adding Kemzyme during the whole experimental period. Feed conversion ratio was significantly improved with rabbits fed SBP diets, as compared with those fed control diet. Moreover, rabbits fed diets supplemented with Kemzyme improved the feed conversion ratio by $3.36 \%$, as compared with those fed diets without Kemzyme. No significant differences could be observed in mortality percentage due to fiber source (AL, SCB and SBP) or enzyme supplementation in diets.

Keywords: growing rabbits, sugarcane bagasse, sugar beet pulp, fiber, growth performance.

\section{INTRODUCTION}

Rabbit feeding is almost associated with diets with high fiber content due to its digestive physiology, there are about 26 million tons of agricultural plant by-products of fibrous nature produced annually in Egypt (Agriculture Economic and Statistics Institute, 2000). Egypt produce 1.86 million tons of sugar cane bagasse annually. This amount contains 168000 tons of starch value, which could be improved to 369000 tons/year by chemical or mechanical treatments. Also, it could be possible to produce 89000 tons of crude protein annually from sugar cane bagasse by some simple treatments. (Egyptian Ministry of agriculture 2004) SCB in Egypt is often discarded by dumping on roads, canals, or by burning resulting in significant contamination of the environment. Sugar beet pulp (SBP) is the solid vegetable matter that remains after sugar extraction from sliced sugar beets, which has been estimated to comprise $6 \%$ dry matter (DM) of the weight of beet root (Talha et al., 2002). Supplementing growing rabbits with exogenous digestive enzymes (Kemzyme) improved digestive enzyme activities and intestinal mucosa morphology coupled with higher growth rate (Attia et al., 2012).

Therefore, the present work tried to determine the effect of using different levels of sugarcane bagasse and sugar beet pulp with or without Kemzyme in diets of growing APRI rabbits on the productive performance. 


\section{El-Tahan et al.}

\section{MATERIALS AND METHODS}

The present study was carried out at Sakha Animal Production Research Station, Animal Production Research Institute (APRI) during the period from September to December 2015. One hundred and forty-four APRI rabbits (Egyptian line selected for litter weight at weaning according to Abou Khadiga et al., 2010) were divided randomly into nine experimental groups of 16 rabbits ( 8 males +8 females) of 5 weeks of age with an average live body weight of $(723 \pm 2 \mathrm{gm})$, were used in this study. Rabbits were equal with respect to body weight and sex. nine experimental diets were formulated to cover all essential nutrient requirements for growing rabbits according to Villamide et al. (2010). The diets as shown in Table 1 were designed to contain 0, 50, 100\% SCB or SBP with or without enzyme.

Table (1): Ingredient and chemical composition of experimental diets.

\begin{tabular}{|c|c|c|c|c|c|c|c|c|c|}
\hline \multirow{3}{*}{ Ingredient } & \multicolumn{9}{|c|}{ Experimental Diet } \\
\hline & \multirow{2}{*}{ Control } & SCB & SCB & SCB & SCB & SBP & SBP & SBP & SBP \\
\hline & & 50 & 100 & $50 \mathrm{E}$ & $100 \mathrm{E}$ & 50 & 100 & $50 \mathrm{E}$ & $100 \mathrm{E}$ \\
\hline \multirow{2}{*}{$\begin{array}{l}\text { Berseem hay } \\
\text { barley }\end{array}$} & 32.00 & 16.00 & 0 & 16.00 & 0 & 16 & 0 & 16 & 0 \\
\hline & 31.00 & 31.00 & 31.40 & 31.00 & 31.40 & 15.4 & 0 & 15.4 & 0 \\
\hline \multirow{2}{*}{$\begin{array}{l}\text { soybean meal } 44 \% \\
\text { wheat bran }\end{array}$} & 20.90 & 23.90 & 27.00 & 23.90 & 27.00 & 22.1 & 23.2 & 22.1 & 23.2 \\
\hline & 9.30 & 12.96 & 16.02 & 12.96 & 16.02 & 15.8 & 22.2 & 15.8 & 22.2 \\
\hline \multirow{2}{*}{$\begin{array}{l}\text { Sugarcane bagasse } \\
\text { Sugar beet pulp }\end{array}$} & 0 & 9.54 & 19.08 & 9.54 & 19.08 & 0 & 0 & 0 & 0 \\
\hline & 0 & 0 & 0 & 0 & 0 & 23.9 & 47.8 & 23.9 & 47.8 \\
\hline Molasses & 3.00 & 3.00 & 3.00 & 3.00 & 3.00 & 3 & 3 & 3 & 3 \\
\hline Limestone & 0.60 & 1.00 & 1.40 & 1.00 & 1.40 & 0.7 & 0.7 & 0.7 & 0.7 \\
\hline Di-Calcium & 2.20 & 1.60 & 1.10 & 1.60 & 1.10 & 2.1 & 2.1 & 2.1 & 2.1 \\
\hline \multirow{2}{*}{$\begin{array}{l}\text { methionine } \\
\text { salt }\end{array}$} & 0.20 & 0.20 & 0.20 & 0.20 & 0.20 & 0.2 & 0.2 & 0.2 & 0.2 \\
\hline & 0.30 & 0.30 & 0.30 & 0.30 & 0.30 & 0.3 & 0.3 & 0.3 & 0.3 \\
\hline Premix $^{(1)}$ & 0.30 & 0.30 & 0.30 & 0.30 & 0.30 & 0.3 & 0.3 & 0.3 & 0.3 \\
\hline Anti-Fungi ${ }^{(2)}$ & 0.10 & 0.10 & 0.10 & 0.10 & 0.10 & 0.1 & 0.1 & 0.1 & 0.1 \\
\hline Anti-oxidant $^{(3)}$ & 0.10 & 0.10 & 0.10 & 0.10 & 0.10 & 0.1 & 0.1 & 0.1 & 0.1 \\
\hline Total & 100 & 100 & 100 & 100 & 100 & 100 & 100 & 100 & 100 \\
\hline \multicolumn{10}{|c|}{ Chemical Analysis (\% as DM): } \\
\hline $\mathrm{DM}(\%)$ & 85.50 & 85.86 & 86.13 & 85.86 & 86.13 & 85.69 & 85.87 & 85.69 & 85.87 \\
\hline Ash $(\%)$ & 5.74 & 5.25 & 4.75 & 5.25 & 4.75 & 5.66 & 5.57 & 5.66 & 5.57 \\
\hline $\mathrm{CP}(\%)$ & 17.90 & 17.90 & 17.90 & 17.90 & 17.90 & 17.92 & 17.91 & 17.92 & 17.91 \\
\hline $\mathrm{EE}(\%)$ & 1.39 & 1.59 & 1.77 & 1.59 & 1.77 & 1.52 & 1.65 & 1.52 & 1.65 \\
\hline $\mathrm{CF}(\%)$ & 13.42 & 13.42 & 13.38 & 13.42 & 13.38 & 13.42 & 13.41 & 13.42 & 13.41 \\
\hline NDF (\%) & 27.76 & 30.12 & 32.32 & 30.12 & 32.32 & 29.10 & 30.41 & 29.10 & 30.41 \\
\hline $\operatorname{ADF}(\%)$ & 16.76 & 16.76 & 16.72 & 16.76 & 16.72 & 15.88 & 14.98 & 15.88 & 14.98 \\
\hline $\operatorname{ADL}(\%)$ & 3.43 & 3.26 & 3.09 & 3.26 & 3.09 & 2.77 & 2.11 & 2.77 & 2.11 \\
\hline Hemicellulose $(\%)$ & 10.99 & 13.36 & 15.60 & 13.36 & 15.60 & 13.22 & 15.44 & 13.22 & 15.44 \\
\hline Methionine (\%) ${ }^{(4)}$ & 0.459 & 0.456 & 0.452 & 0.456 & 0.452 & 0.442 & 0.425 & 0.442 & 0.425 \\
\hline \multirow{2}{*}{$\begin{array}{l}\text { Calcium (\%) } \\
\text { Phosphorus }(\%)^{(4)}\end{array}$} & 1.26 & 1.25 & 1.25 & 1.25 & 1.25 & 1.27 & 1.27 & 1.27 & 1.27 \\
\hline & 0.833 & 0.815 & 0.811 & 0.815 & 0.811 & 0.822 & 0.830 & 0.822 & 0.830 \\
\hline DE (kcal) & 2448 & 2447 & 2446 & 2447 & 2447 & 2449 & 2449 & 2449 & 2449 \\
\hline
\end{tabular}

(1) PESTMIX produced by Pestar Company, China.

(3) FEEDOX® dry, IMP EXTRACO (Belgium).

(2) Mycostat, Agil, England.

KEMZYME® is a multi-enzyme blend of Kemin Agrifoods Europe, containing $3000 \mu / g$ betaglucanase,5000 $\mu / g$ cellulase, $450 \mu / g$ alfa-amylase and $450 \mu / g$ protease and lipase was used.

All diets were nearly iso-nitrogenous, iso-caloric on the basis of metabolizable energy and contained similar levels of crude fiber and micro elements. Rabbits were housed in individual galvanized wire pyramidal batteries $(30 \times 25 \times 35 \mathrm{~cm})$ with feeder and automatic nipple drinkers. The batteries were arranged in rows in a windowed house naturally ventilated. All rabbits were kept under the same management conditions. Feed and water were supplied ad libitum. Individual body weight and feed intake were recorded weekly from 5 weeks until 13 weeks of age. Daily weight gain and feed conversion rate were calculated. Relative growth rate and performance index 
were calculated according to North, (1981). Mortality and the clinical health status of all rabbits were monitored daily.

Data was statistically analyzed using the general linear GLM procedure (SAS, 2000). The application of the least significant ranges among the different treatment means was done according to Duncan (1955).

\section{RESULTS AND DISCUSSION}

The effect of experimental diets on growth performance from 5 to 13 weeks of age is presented in Table (2). It is clearly shown that no significant differences in body weight could be detected in the initial body weight $(5$ week of age). Rabbits fed diets containing SBP50 and SBP50E had the highest $(\mathrm{P}<0.001)$ body weight $(2200.6$ $\mathrm{g})$; while those fed diet SCB 100 had the lowest $(\mathrm{P}<0.001)$ body weight $(1955.3 \mathrm{~g})$ in the whole growing period. However, no significant differences between rabbits fed diets containing SBP50 or SBP50E could be observed. Also, the rabbits fed diets containing kemzyme treated SCB either 50 or 100 had a significant increase in body weight than those fed diets containing untreated SCB. Rabbits fed diets containing SBP50 and SBP50E recorded the highest values of daily weight gain followed by those received control diet $(26.4,26.4$ and $25.4 \mathrm{~g}, \mathrm{P}<0.0001$, respectively), while the lowest value was observed for rabbits fed SCB100 diet (22.0 g, P<0.0001). Also, Abd EL-Latif et al. (2012) concluded that rabbits fed diets containing 25 and 100\% SBP replacement of berseem hay recorded significant $(\mathrm{P}<0.05)$ heavier body weight than those fed control diet, at marketing age $(16$ weeks $)$. They also found that rabbits fed $25 \%$ SBP recorded the best $(\mathrm{P}<0.05)$ body gain followed by those fed $100 \%$ SBP compared with other dietary treatments, during the entire period (6-16 weeks of age). Rabbits fed control diet recorded the highest daily feed intake, while those fed SCB100E recorded the lowest value $(81.9$ vs. $76.1 \mathrm{~g}$; $\mathrm{P}<0.0001)$. These results were in harmony with those obtained by El-Adawy et al. (2000) who concluded that replacement of 50 or $100 \%$ lucerne hay with SBP in rabbits' diet significantly decreased $(\mathrm{P}<0.01)$ daily feed consumption and growth performance index but increased the feed conversion ratio $(P<0.01)$ than the control. Rabbits fed SBP50E diet recorded the best feed conversion ratio, while those fed SCB100 diet had the worst value $(\mathrm{P}<0.0001)$. Also, El-Marakby (2003) and Allam et al. $(2006)$ concluded that there was an improvement in FC ratio for the rabbits fed diets contained biologically treated poor quality roughages which may be due to the high live body weight gain with low feed intake. The mortality among all experimental diets was in normal range.

Table (2): Effect of experimental diets on growth performance of growing APRI-line rabbits from 5 to 13 weeks of age:

\begin{tabular}{|c|c|c|c|c|c|c|c|c|c|c|c|}
\hline \multirow{3}{*}{ Parameter } & \multirow{3}{*}{ Control } & \multicolumn{4}{|c|}{ Sugarcane bagasse } & \multicolumn{4}{|c|}{ Sugar beet pulp } & \multirow{3}{*}{ MSE } & \multirow{3}{*}{ Sig. } \\
\hline & & SCB & SCB & SCB & SCB & SBP & SPB & SBP & SBP & & \\
\hline & & 50 & 100 & $50 E$ & $100 \mathrm{E}$ & 50 & 100 & $50 E$ & $100 \mathrm{E}$ & & \\
\hline Initial Body Weight (g) & 721.6 & 721.9 & 724.7 & 723.8 & 724.1 & 724.1 & 725.0 & 723.8 & 723.1 & 9.16 & NS \\
\hline Final Body Weight (g) & $2144.7^{a b}$ & $2058.1^{c d}$ & $1955.3^{e}$ & $2120.3^{b c}$ & $2038.4^{d}$ & $2200.3^{\mathrm{a}}$ & $2118.4^{b c}$ & $2200.6^{\mathrm{a}}$ & $2073.1^{c d}$ & 22.56 & $* * *$ \\
\hline $\begin{array}{l}\text { Daily Weight Gain } \\
\text { (g) }\end{array}$ & $25.4^{\mathrm{ab}}$ & $23.9^{\text {cd }}$ & $22.0^{\mathrm{e}}$ & $24.9^{\mathrm{bc}}$ & $23.5^{d}$ & $26.4^{\mathrm{a}}$ & $24.9^{b c}$ & $26.4^{\mathrm{a}}$ & $24.1^{\mathrm{cd}}$ & 0.42 & $* * *$ \\
\hline Feed Intake (g/d) & $81.9^{a}$ & $79.3^{\mathrm{cd}}$ & $76.9^{\text {ef }}$ & $78.5^{\mathrm{cd}}$ & $76.1^{\mathrm{f}}$ & $80.6^{b}$ & $78.4^{d}$ & $79.6^{c}$ & $77.4^{\mathrm{e}}$ & 0.34 & $* * *$ \\
\hline $\begin{array}{l}\text { Feed Conversion } \\
\text { Ratio }\end{array}$ & $3.258^{b c}$ & $3.342^{b}$ & $3.523^{\mathrm{a}}$ & $3.155^{\mathrm{de}}$ & $3.253^{b c}$ & $3.067^{\text {de }}$ & $3.159^{d e}$ & $3.035^{\mathrm{e}}$ & $3.216^{\mathrm{cd}}$ & 0.05 & $* * *$ \\
\hline $\begin{array}{l}\text { Relative Growth } \\
\text { Rate }\end{array}$ & $99.1^{\mathrm{ab}}$ & $96.1^{b}$ & $91.8^{\mathrm{c}}$ & $98.2^{\mathrm{ab}}$ & $95.2^{\mathrm{bc}}$ & $100.9^{a}$ & $98.0^{\mathrm{ab}}$ & $100.9^{a}$ & $96.6^{b}$ & 1.20 & $* * *$ \\
\hline $\begin{array}{l}\text { Performance Index } \\
(\%)\end{array}$ & $67.1^{b c}$ & $62.1^{\mathrm{c}}$ & $56.1^{d}$ & $67.5^{\mathrm{bc}}$ & $62.9^{c}$ & $72.0^{\mathrm{ab}}$ & $67.4^{\mathrm{bc}}$ & $73.2^{\mathrm{a}}$ & $64.7^{c}$ & 1.78 & $* * *$ \\
\hline Mortality (\%) ${ }^{(1)}$ & 6.25 & 6.25 & 6.25 & 6.25 & $\mathbf{0}$ & 6.25 & $\mathbf{0}$ & 6.25 & 6.25 & - & - \\
\hline
\end{tabular}




\section{El-Tahan et al.}

\section{CONCLUSIONS}

From Our results can be concluded that it is possible to include up to $47.8 \%$ of sugar beet pulp with or without kemzyme in growing rabbit's diets with significant increase in growth performance, while it is possible to include up to $9.54 \%$ of sugarcane bagasse with kemzyme in growing rabbit's diets without significant differences in growth performance.

\section{REFERENCES}

Abd EL-Latif, S.A.; Toson, M.A.; Aattiat, H. EL Bogdadi and Abdel-Rahman, M. Kh. (2012). Effect of Replacing Hay by Sugar Beet Pulp in Growing Rabbit Diets on Some Productive, Metabolic Responses and Economical Efficiency. Egyptian J. Anim. Prod., 47 Suppl. Issue, Nov. (2012):141-149.

Abou Khadiga, G.; Youssef, Y. M. K.; Saleh, K.; Nofal, R. Y. and Baselga, M., (2010). Genetic trend in selection for litter weight in two maternal lines of rabbits in Egypt. World Rabbit Sci., 18: 27 - 32.

Agriculture Economic and Statistics Institute 2000.Agric. Economics Part 1. Public by Agric. Res. Center, Ministry of Agriculture, Egypt.

Allam, S.M.; Al-Badawi, T.M.; El-Amany, Hanaa H. and Mohamed, Shereen H. (2006). Improving sugar beet pulp through biological treatment and its use in sheep ration. Egyptian J. Nutr. and Feeds 9(2): 235.

Attia, K.A., Sohair Y. Saleh, S. Abd El-hamidSafaa, A. ZakiAmal, A. El-Sawy Mohamed (2012). Effects of Exogenous Multienzyme Feed Additive (Kemzyme) on the Activities of Certain Digestive Enzymes and Intestinal Morphology in Growing Rabbits. J Agr. Sci. 4, 3.

Duncan, D. B. (1955). Multiple range and multiple F. tests. Biometrics, 11, 1-42.

Egyptian Ministry of Agriculture (2004). Economic Affairs, Sector of Agricultural Statistics. (1): Nov. 2004.

El-Adawy, M.M.; Borhami, B.E. and Bassuny S.M. (2000). Effect of Lacto-A-Bac vs Stafac*20 on the performance of growing New Zealand White rabbits. Egyptian J. of Rabbit Science, 10(1): 43- 59.

El-Marakby, K. M. A. (2003). Biological treatments of poor quality roughe and its effect on productive performance of ruminants. MSc. Thesis. Animal Production Department, Faculty of Agriculture, Zagazig University, Egypt.

North, M. O. (1981). Commercial Chicken. Production Annual. $2^{\text {nd }}$ Edition, Production $6^{\text {th }}$ Ed. Interstate Printers and Publishers. INC., USA.

Talha, M.H.; Mourad, R.I.; Zaza, G.H. and Ragheb, E.E. (2002). Effect of partial substitution of corn grains by dried sugar beet pulp in growing lambs' rations on their productive performance, Journal of Agriculture Science, Mansoura University, 27, 5193-5199.

SAS (2000). SAS User's guide: Statistics. SAS Inst. Inc., Cary, NC.

Villamide M.J., Maertens L., de Blas C. (2010). Feed Evaluation. In: De Blas C., Wiseman J. (Eds). The nutrition of the Rabbit (2nd Edition). CABA Publishing. CAB International, Wallingford Oxon, UK, 151-162. 
تأثير استخدام مصاصة قصب السكر وتفل بنجرالسكر مع أو بدون انزيمات في علائق الأرانب النامية على: 1- الأداء الإنتاجي للأرانب النامية

حسام مددوح عبده الطحان 1'، محمد أحمد محمد سيد1، وائل عوض محمود مرسي1 ، فوزي صديق عبد الفتاح إسماعيل2 ، محمد رأفت سليمان الجوجري2

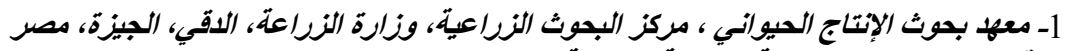

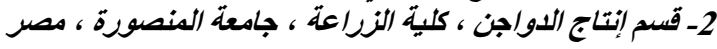

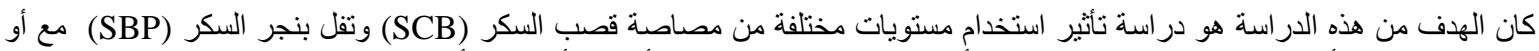

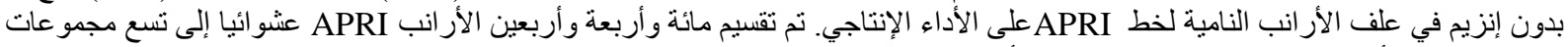

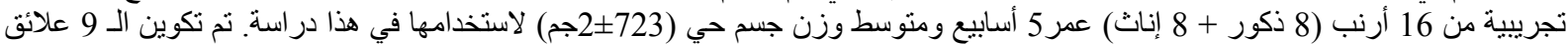

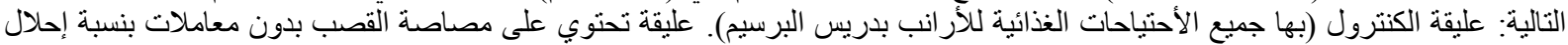

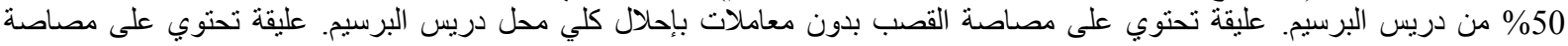

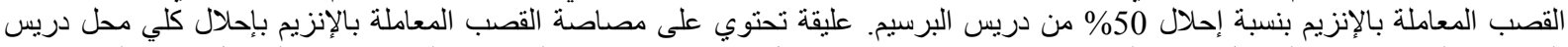

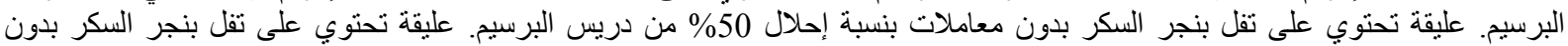

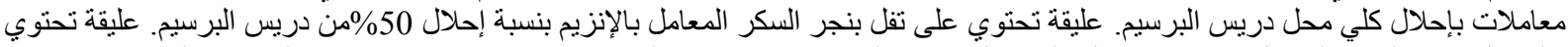

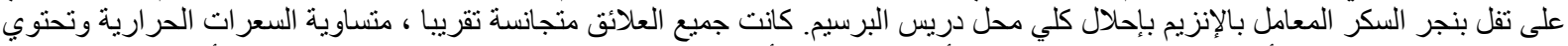

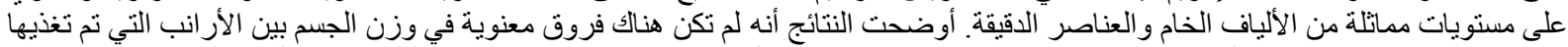

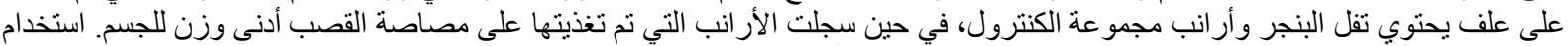

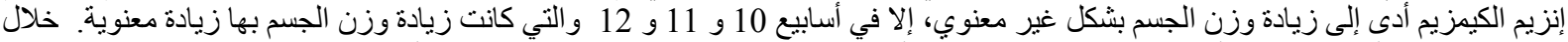

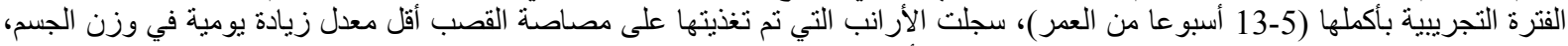

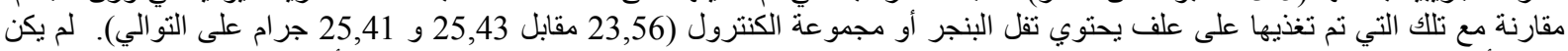

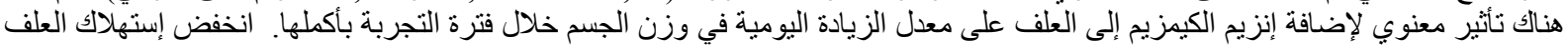

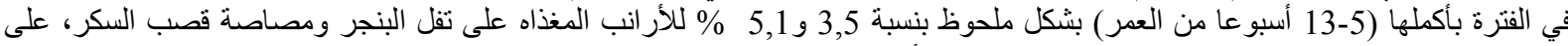

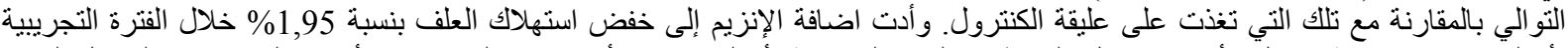

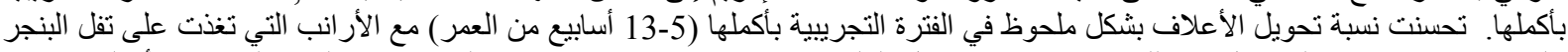

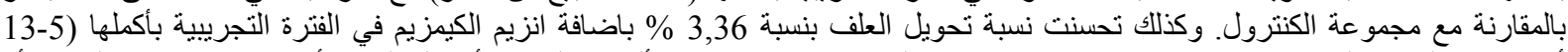

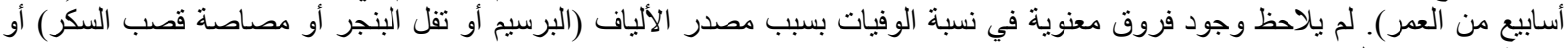
إضافة الإنزيم في العلائق. 